\title{
Tata Kelola Keuangan Sederhana bagi UMKM di Kapuk Muara
}

\author{
Wiwit Irawati ${ }^{1}$, Lioni Indrayani ${ }^{2}$, Harry Barli ${ }^{3}$ \\ 1,2,3 Akuntansi S1, Fakultas Ekonomi, Universitas Pamulang \\ E-mail: ${ }^{1}$ wiwitira@unpam.ac.id, ${ }^{2}$ dosen02626@unpam.ac.id, ${ }^{3}$ dosen01058@unpam.ac.id
}

\begin{abstract}
Abstrak
Berdasarkan Undang-Undang Nomor 20 Tahun 2008 mengenai Usaha Mikro Kecil Menengah, Yayasan Dian Mandiri berkomitmen untuk menjadi aset bagi bangsa Indonesia sesuai dengan visinya mentransformasi kehidupan melalui pengembangan Usaha Mikro, Kecil dan Menengah. Komitmen pengembangan Usaha ini diwujudkan dengan membantu pengembangan kegiatan usaha mitra. Dalam pengembangan usaha, para mitra seringkali menghadapi permasalahan dalam perencanaan keuangan kegiatan usaha mereka, terutama di masa pandemi ini. Dengan adanya kegiatan pengabdian masyarakarat ini, diharapkan menjadi solusi terhadap permasalahan tata kelola keuangan mitra Dian Mandiri. Selanjutnya, melalui program pengajaran tentang tata kelola keuangan sederhana dari Universitas Pamulang diharapkan menjadi sarana pemberdayaan masyarakat sekitar.
\end{abstract}

Kata kunci: mitra; tata kelola; UMKM

\begin{abstract}
Based on the Regulation Number 20 Year 2020 regarding Small Micro Medium Enterprise, Dian Mandiri Foundation is committed to be an asset for Indonesia in accordance with its vision which is to transform life through development of Small Micro Medium Enterprise. The commitment to develop enterprise is attained by helping business development their partners.

In managing development of business, the partners often face problem in bookkeeping their business, especially at this pandemic covid-19. Therefore, by doing the community service activity from Universitas Pamulang, it is expected to become the solution to finance governance problem of Dian Mandiri cooperative's partners.
\end{abstract}

Key words: governance; partner; MSME

\section{PENDAHULUAN}

Pada era globalisasi sekarang ini, semua pihak berlomba-lomba menjalankan Usaha Mikro, Kecil dan Menengah. Salah satu pihak yang berfokus pada pengembangan usaha mikro adalah Yayasan Dian Mandiri yang didirikan pada tahun 1998 di wilayah Kota Tangerang. Yayasan Dian Mandiri didirikan sebagai perwujudan respon atas krisis finansial yang terjadi di Indonesia pada tahun tersebut. Dian Mandiri telah melayani 70.000 klien aktif yang tersebar di wilayah Jabodetabek (Jakarta, Bogor, Depok, Tangerang dan Bekasi), Aceh, Banten, Jawa Barat, Yogyakarta dan Surabaya. Melalui 22 kantor cabangnya, Diman tetap berkomitmen untuk menjadi aset bagi bangsa Indonesia sesuai dengan visinya mentransformasi kehidupan melalui pengembangan Usaha Mikro, Kecil dan Menengah (UMKM) berdasarkan UndangUndang Nomor 20 Tahun 2008[1]. 
Mitra Dian Mandiri adalah warga masyarakat yang mayoritas adalah perempuan dan para ibu rumah tangga, yang memiliki usaha kecil seperti menjual produk maupun jasa, membuka warung makan, nelayan dan penjual segala kebutuhan di pasar. Mitra Dian Mandiri dibentuk menjadi kelompok dengan anggota lima belas sampai dua puluh anggota. Setiap kelompok memiliki satu ketua dan satu bendahara. Para pelaku usaha ini belum terbiasa melakukan kontrol pendapatan yang masuk dan pengeluaran usaha yang terjadi. Pola tersebut, menyebabkan masalah di kemudian hari. Masalah yang terjadi biasanya adalah bangkrutnya usaha kecil mereka. Para mitra terbiasa memakai semua pendapatan usaha untuk memenuhi kebutuhan sehari-hari. Hal tersebut karena belum terbentuknya kedisiplinan dalam penggunaan pendapatan yang mengakibatkan modal usahanya pun tidak bertambah tetapi malah ikut digunakan menutupi kebutuhan sehari-hari. Belum lagi diperberat dengan pandemi Covid-19 saat ini. Para mitra belum memahami pentingnya tata kelola keuangan sederhana. Pentingnya memahami tata kelola keuangan sederhana, sangat dibutuhkan dalam pengelolaan usaha. Setiap usaha walaupun itu hanya berskala kecil perlu membuat pencatatan walaupun hanya dalam bentuk sederhana. Karena dengan pencatatan keuangan, para pelaku usaha dapat melihat kondisi keuangannya dan membuat rencana atau keputusan dalam usahanya. Bila para mitra sudah memahami bagaimana membuat tata kelola keuangan sederhana, tentunya pada saat menjalankan usaha dan mulai melihat pendapatan tidak sesuai dengan pengeluaran harian, mereka dapat memutuskan menghentikan usaha tersebut dan mulai berpikir untuk beralih ke usaha lain. Usaha para mitra ini biasanya juga usaha musiman yang sedang digemari masyarakat sekitar. Contohnya seperti pada saat musim menjual es kepal milo, mereka berjualan es kepal milo. Pada saat masyarakat mulai jenuh dengan es kepal milo, mereka berjualan cilok. Saat ini yang mereka jual adalah varian kopi dalgona.

Sebagaimana tertuang dalam Undang-Undang Nomor 12 tahun 2012 tentang Pendidikan Tinggi, sebagai seorang dosen maka kewajiban utamanya adalah untuk melakukan Tri Dharma Perguruan Tinggi yakni kewajiban untuk menyelenggarakan Pendidikan, penelitian, dan pengabdian kepada masyarakat. [2]. Pada masa Pandemi COVID 19 ini kebutuhan masyarakat untuk dikuatkan, diarahkan menjadi lebih terasa. Dengan perekonomian yang sangat terimbas pandemi, di mana satu keluarga bisa kehilangan mata pencahariannya, maka usaha mikro, kecil dan menengah dapat menjadi salah satu jalan keluar dari permasalaha perekonomian. Tentunya dengan manajemen yang baik agar usaha yang digeluti dapat bertahan dan bertumbuh di tengah pandemi. Pembinaan tentang tata kelola keuangan sederhana dari Tim Dosen Prodi Akuntansi Universitas Pamulang, sangat berguna bagi mitra Dian Mandiri, karena melihat potensi yang ada pada organisasi tersebut sekaligus dapat membantu mencapai salah satu tujuan dari gerakan tersebut yakni meningkatkan kesejahteraan masyarakat [3]. Sebagaimana yang dihasilkan dari penelitian Sulila (2018) yang menyatakan peran perguruan tinggi yang dilaksanakan melalui pengabdian masyarakat difokuskan pada upaya konkrit secara bertahap dan terukur dalam meningkatkan Pemberdayaan Masyarakat, maka kegiatan PKM ini juga diharapkan menjadi suatu rangkaian kegiatan yang membina para pelaku usaha kecil sehingga secara bertahap akan mengalami kemajuan dalam usaha mereka.[4]

Menurut Kamus Besar Bahasa Indonesia (KBBI) tata adalah aturan, susunan atau cara menyusun. Sedangkan kelola adalah mengelola, mengendalikan dan menyelenggarakan. Tata kelola adalah kombinasi proses dan struktur untuk menginformasikan, mengarahkan, mengelola dan memantau kegiatan dalam rangka pencapaian tujuan [5]. Marry Parker Foller mendefinisikan tata kelola sebagai seni atau proses dalam menyelesaikan sesuatu yang terkait dengan pencapaian tujuan. Dalam penyelesaian akan sesuatu tersebut, terdapat tiga faktor yang terlibat adanya penggunaan sumber daya organisasi baik sumber daya manusia maupun faktorfaktor produksi lainnya. Proses yang bertahap mulai dari perencanaan, perorganisasian, pengarahan dan pengimplementasian, hingga pengendalian pengawasan dan adanya seni dalam menyelesaikan pekerjaan. Sutrisno (2013) berpendapat bahwa, fungsi tata kelola atau manajemen keuangan terdiri dari tiga keputusan utama yang harus dilakukan oleh suatu organisasi yaitu: a) Keputusan Investasi b)Keputusan pendanaan dan c)keputusan dividen. 
Maka dapat disimpulkan fungsi tata kelola keuangan memiliki tahap-tahap dalam pelaksanaannya, yaitu: tahap perencanaan, tahap pengalokasian dan tahap pertanggungjawaban[6].

Melihat latar belakang pendidikan pelaku UMKM, nampak bahwa para ibu belum memiliki pemahaman yang memadai dalam melakukan tata kelola keuangan sederhana. Permasalahan utama mitra yang sudah dijelaskan sebelumnya. Masalah yang terjadi biasanya adalah bangkrutnya usaha kecil mereka karena belum terbentuknya kedisiplinan dalam mencatat semua kegiatan usaha kecil mereka. Para mitra masih terbiasa memakai pendapatan usahanya untuk kebutuhan sehari-hari. Kebiasaan tersebut yang mengakibatkan modal usahanya pun tidak bertambah malah berkurang bahkan habis. Mereka pun pada akhirnya juga tidak mengetahui penyebab usahanya bangkrut dan modalnya habis. Dan seperti itu masih berulang selama belum mendisiplinkan diri dalam melakukan perencanaan keuangan.

Setelah ditelusuri salah satu penyebab kegagalan usaha mereka adalah para mitra belum memahami pentingnya pembukuan sederhana. Mitra Dian Mandiri berasal dari masyarakat kalangan menengah ke bawah yang memiliki usaha skala kecil yang biasanya menjalankan usahanya dengan mengabaikan perencanaan keuangan usahanya. Mereka kebanyakan masih beranggapan meitu sulit dan rumit. Alasan lainnya mereka lebih fokus terhadap penjualan makanannya.

Masalah utama para mitra adalah mengenai tata kelola administrasi, maka solusi yang ditawarkan kepada mitra adalah:

1. Membantu mitra mengenali jenis usahanya, bagaimana cara mengelola administrasi harian serta bagaimana aktivitas pembukuan yang baik.

Langkah awal dengan mendengar sharing mereka tentang usaha yang sedang berjalan dan apa permasalahan menyangkut aktivitas keuangan dan usaha yang sering dihadapi oleh mitra Dian Mandiri.

2. Membantu menjelaskan bagaimana pengelolaan administrasi atau pencatatan transaksi harian dengan sederhana.

Dalam hal ini memberikan pelatihan tata kelola keuangan yang sudah baku dan dikembangkan di Program Studi Akuntansi Universitas Pamulang.

Spesifikasi dari kegiatan pendampingan pelatihan tata kelola keuangan sederhana adalah sebagai berikut:

a. Para Mitra akan diberikan praktik pencatatan keuangan sederhana yang baik.

Pencatatan keuangan sederhana dapat dimulai dengan membuat catatan pendapatan dan pengeluaran di buku tulis biasa ataupun buku kas.

b. Dengan pengajaran, pelatihan dan praktik, diharapkan mitra dapat mengetahui kondisi keuangan usahanya.

3. Memberikan pendampingan dalam kegiatan pelatihan dan praktik tata kelola keuangan sederhana bagi para mitra berkaitan dengan tata kelola keuangan.

a. Para Mitra dibagi dalam kelompok-kelompok kecil, narasumber mulai menjelaskan aktivitas keuangan apa saja yang perlu dicatat mulai dari modal usaha di awal, pengeluaran harian, pemasukan pendapatan harian.

b. Menjelaskan bahwa modal awal usaha tidak boleh dipergunakan untuk kebutuhan sehari-hari. Modal yang baik seharusnya nilainya semakin lama semakin besar ditambahkan dari perolehan pendapatan harian. Modal harus dijaga

c. Mulai memberikan contoh transaksi harian, seperti pembelian plastik kemasan, biaya bensin motor untuk mengantar pesanan pelanggan, penggunaan gas dan minyak goreng yang sering luput dari pencatatan pengeluaran harian usaha.

d. Menjelaskan bagaimana melakukan prosedur pencatatan transaksi keuangan harian. Bagian pemasukan kas di bagian mana, lalu bagian pengeluaran kas di bagian mana. Transaksi apa saja yang menambah kas juga transaksi apa saja yang mengurangi kas juga pendapatan. 
e. Memberi pengarahan mengenai apa itu cadangan resiko. Dan memberi pandangan bagi para mitra bahwa mereka harus punya biaya cadangan resiko dalam aktivitas usahanya. Cadangan resiko dimanfaatkan pada saat terjadi kerusakan pada produk yang dijual. Contoh: bagi kelompok yang usahanya sebagai nelayan, maka harus mempunyai cadangan resiko untuk menutup kerugian saat ikannya tidak laku terjual di pasar.

4. Evaluasi dilakukan untuk melihat dampak apa yang timbul setelah kegiatan pendampingan selesai. Bagaimana para mitra Dian Mandiri merasakan manfaat dari kegiatan Pengabdian ini. Bagaimana kemajuan usaha mereka setelah menerapkan materi pendampingan kegiatan pengabdian dalam usahanya.

\section{METODE PELAKSANAAN}

Kegiatan pengabdian dilaksanakan pada hari Senin, 29 Juni 2020 dimulai pada pukul 10.00 WIB berlokasi di Kelurahan Kapuk Muara, Penjaringan, Jakarta Utara. Kegiatan pengabdian masyarakat ini dilaksanakan dalam berbagai tahapan yaitu:

(1) Tahapan persiapan kegiatan, dilakukan untuk menyesuaikan kebutuhan mitra, waktu pelaksanaan kegiatan pengabdian dan tempat untuk melaksanakan kegiatan pengabdian

(2) Tahapan persiapan berikutnya adalah tim pengabdi mempersiapkan materi dan bahan ajar yang dibutuhkan saat pelaksaan pengabdian, sekaligus mempersiapkan paket sembako sebagai buah tangan di masa pandemi ini

(3) sebelum pelatihan dilaksanakan, para peserta pengabdian diberikan penjelasan mekanisme kegiatan serta tujuan kegiatan pengabdian dilaksanakan. Penjelasan mengenai perencanaan keuangan dan juga dana cadangan

(4) Pelaksanaan pengabdian dengan melakukan pelatihan tata kelola keuangan dalam mencari solusi usaha para pelaku UMKM

(5) Tahap akhir adalah sesi sharing dan tanya jawab mengenai permasalahan usaha pelaku UMKM.

\section{HASIL DAN PEMBAHASAN}

Pelaksanaan kegiatan pengabdian diawali dengan tahapan pembagian masker dan hand sanitizer sebelum memasuki ruangan pelatihan. Hal ini dilakukan dalam memenuhi protokoler Kesehatan dalam rangka pencehagan penularan covid-19. Setelah semua peserta memakai hand sanitizer dan masker, mereka mengisi absen peserta dan mengambil handout pelatihan juga pulpen yang dibagikan oleh mahasiswa prodi Akuntansi Unpam yang juga sebagai peserta dan tim Kegiatan Pengabdian Masyarakat.

Kegiatan pengabdian dimulai dengan melakukan pre-test. Anggota Tim Pengabdian sudah menyiapkan 1 lembar kertas yang dibagikan kepada semua peserta pelatihan. Dalam lembar tersebut berisi sebuah studi kasus. Para peserta diminta menjawab atau memilih transaksi-transaksi keuangan berdasarkan prioritasnya, dimulai dari yang sangat penting sampai kepada yang kurang pentung. Setelah semua peserta mengisi lembar tersebut, narasumber memulai diskusi dengan ketua mitra kelompok yaitu Ibu Een. Berdasarkan hasil diskusi, diketahui bahwa para pelaku UMKM menghendaki adanya pelatihan tentang tata kelola keuangan sederhana dalam menghadapi dan melewati masa pandemi covid-19. Berdasarkan hasil wawancara diketahui peserta pengabdian belum memiliki latar belakang pengetahuan mengenai tata kelola keuangan usaha yang baik dan benar sehingga diharapkan materi pelatihan yang diberikan dapat membantu mengatasi permasalahan, sekaligus menjadi solusi keuangan dalam usaha mereka. Oleh sebab itu, tim pengabdian memutuskan mengadakan pelatihan secara terbatas hanya dengan mengundang 30 peserta pelaku UMKM warung makan. Akan tetapi di masa pandemi covid-19 ada aturan protokoler kesehatan 
dalam mengadakan pertemuan yaitu harus 50 persen peserta yang hadir. Dengan pembatasan peserta ini tidak mengurangi kualitas pelatihan sehingga tetap berjalan lebih efektif, dapat mengetahui permasalahan dengan mendalam dan tentunya memberikan solusi. Pembatasan peserta ini juga sebagai upaya pelaksanaan pengabdian masyarakat dengan tetap memperhatikan protokoler kesehatan di masa pandemi.

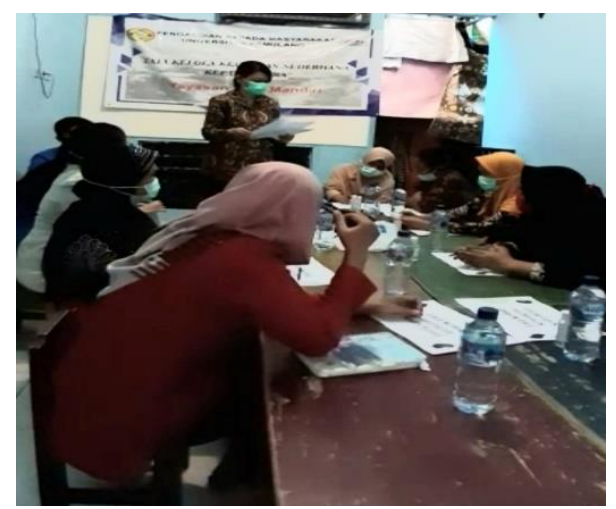

Gambar 1 Pelatihan Acara Pengabdian

Kegiatan pengabdian berjalan baik dan lancar yang dimulai dari Doa Pembukaan dilanjutkan kata sambutan dari pihak Dian Mandiri dan Ibu Ketua mitra kelompok UMKM.

Kegiatan pengabdian selanjutnya adalah pemberian materi oleh tim pengabdian dengan pokok bahasan yang disampaikan mengenai (1)memisahkan uang untuk kebutuhan pribadi dengan uang usaha (2)melakukan perencanaan keuangan dengan bijak (3) melakukan pencatatan untuk seluruh transaksi keuangan (4) menyediakan dana cadangan.

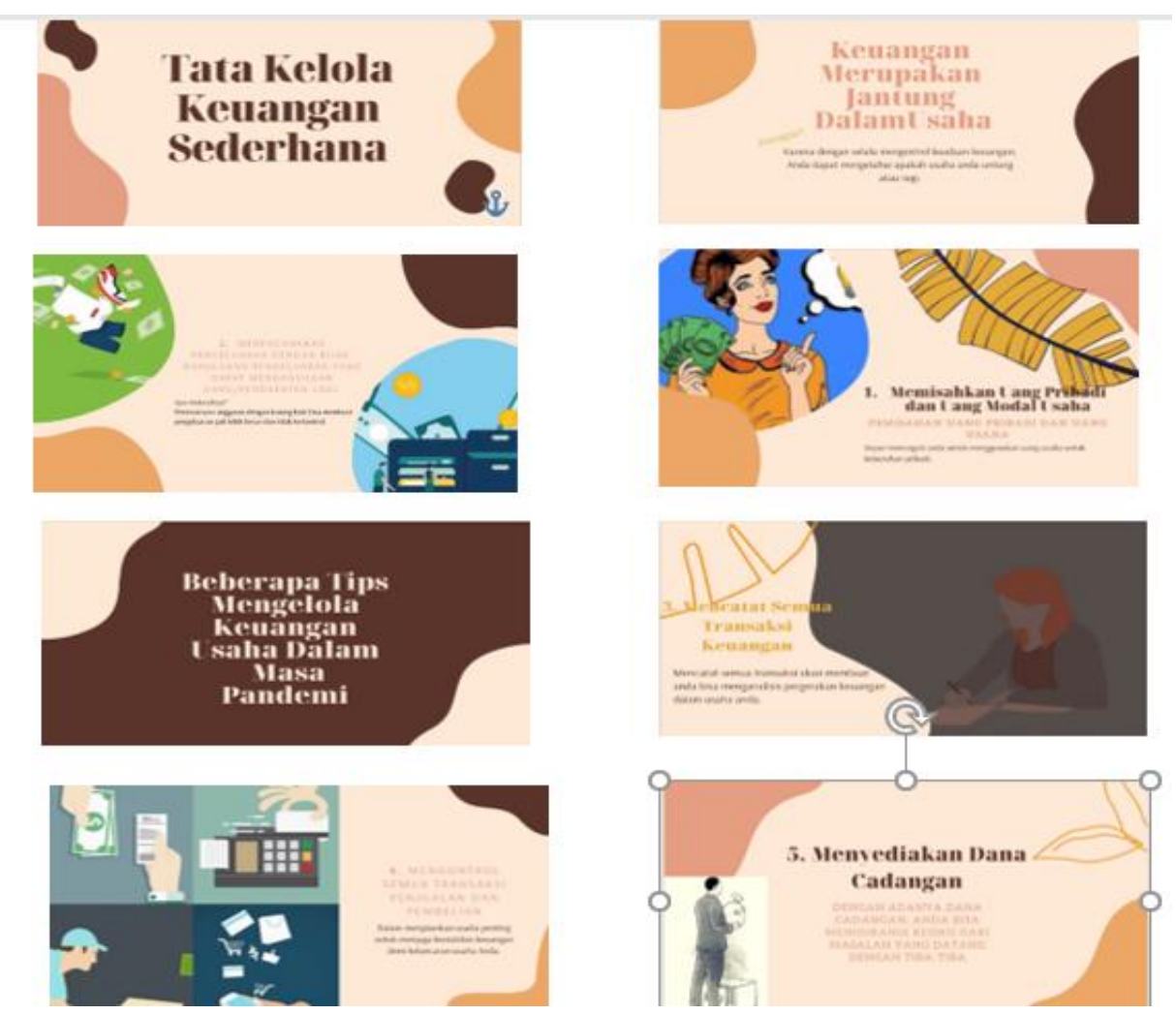

Gambar 2 Slide Presentasi 
Tujuan pelatihan tata kelola keuangan sederhana secara umum sudah tercapai. Para peserta pengabdian juga mulai menemukan permasalahan dalam pengelolaan keuangan usaha mereka selama ini. Kesalahan-kesalahan tersebut yang membuat usaha mereka belum bisa maju dan stagnan. Peserta pengabdian sangat antusias memberikan pertanyaan yang terkait dengan solusi keuangan untuk usaha mereka. Dari hasil diskusi diketahui bahwa semua peserta belum atau terlupa membuat perencanaan sebelum melakukan aktivitas keuangan, tidak mencatat pemasukan usaha dengan tertib dan tidak membuat atau memisahkan dana cadangan.

Setelah pemaparan materi, tim pengabdian melakukan post test dengan membagikan kertas dan meminta para peserta pengabdian mengisi dengan modal awal usaha, pengeluaran/belanja per hari dan pemasukan harian. Dari hasil tulisan mereka sendiri, tim pengabdian menjelaskan apa yang terjadi. Untung ataukah rugi. Para peserta pengabdian juga bercerita mengenai alasan modal usaha yang selalu terpakai biasanya adalah untuk keperluan mendadak, misalnya sakit ataupun hanya untuk alasan sepele, seperti cucu yang minta jajan. Tim pengabdian memberikan solusi dan cara memisahkan dana cadangan dari setiap pendapatan harian yang diperoleh.

Setelah materi selesai dipaparkan, dilanjutkan dengan pembagian buah tangan yaitu paket sembako. Paket sembako berisi beras 5 kilo, gula pasir 2 kilo dan minyak goreng 1 liter. Buah tangan ini diharapkan dapat memberi sedikit manfaat dan berguna bagi para peserta di masa pandemi ini. Di mana sebagian dari ibu-ibu peserta saat ini mengambil alih sebagai pencari nafkah rumah tangga, karena suami mereka yang dirumahkan (pemutusan hubungan kerja) akibat terdampak pandemic covid-19.
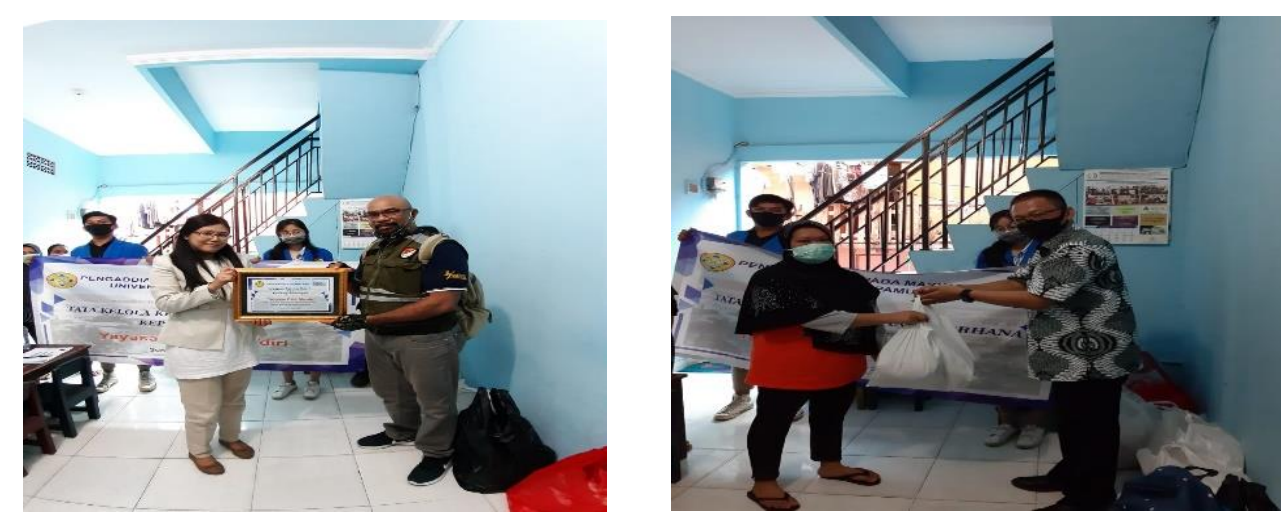

Gambar 3 Pemberian Plakat dan Pembagian Sembako

Kegiatan pengadian kepada masyarakat ini secara keseluruhan dinilai berhasil dan sesuai tujuan. Materi yang dipersiapkan dapat diteruskan kepada peserta dengan baik dan para peserta pengabdi juga merasakan manfaat yang luar biasa yaitu tekad untuk lebih disiplin dalam mengelola keuangan usaha terutama dalam menghadapi masa pandemic covid-19 yang belum berakhir.

\section{KESIMPULAN}

Berdasarkan hasil kegiatan pengabdian diketahui bahwa peserta memahami dan berniat untuk disiplin dan selalu melakukan perencanaan dalam keuangan usaha mereka. Dengan berbekal pelatihan dari Tim Dosen Akuntansi Universitas Pamulang, diharapkan para peserta dapat mulai menerapkan perencanaan dalam kegiatan usaha warung makan mereka. Para ibuibu peserta sudah membuat perencanaan apa saja dalam usahanya, apa saja yang harus dihemat tanpa mengurangi mutu lauk pauk yang mereka jual. Para peserta juga memiliki tekad untuk selalu disiplin dan menyiapkan dana cadangan dalam usaha mereka dalam menghadapi masa pandemi yang belum berakhir. 


\section{DAFTAR PUSTAKA}

[1] UUD RI. 2008. Undang-Undang Republik Indonesia Nomor 20. Usaha Mikro Kecil Menengah.

[2] Indonesia, P. R. (2012). Undang-undang Republik Indonesia Nomor 12 tahun 2012 tentang Pendidikan Tinggi. Jakarta: Negara Republik Indonesia

[3]www.dianmandiri.co.id Profil Koperasi Dian Mandiri

[4] Sulila, I. (2018). Penguatan kapasitas tata kelola keuangan dan produksi bagi kelompok masyarakat pengrajin karawo Desa Wisata Religius Bongo Kabupaten Gorontalo. Jurnal Pengabdian Kepada Masyarakat, 24(2), 610-616.

[5] KBBI. (2004). Jakarta: Balai Pustaka.

[6] Sutrisno. (2013). Manajemen Keuangan. Yogyakarta. Ekonisia 